\title{
Influence of School Managers' Training on Disaster Risk Management in Public Secondary Schools within Nairobi City County Kenya
}

\author{
Ignatius N. Munyiri*, Ruth W. Thinguri, Paul Edabu \\ School of Education, Mount Kenya University, P.O. Box 342-01000, Thika, Kenya \\ *Corresponding author: ignatiusmunyiri@gmail.com
}

Received November 02, 2019; Revised December 10, 2019; Accepted December 21, 2019

\begin{abstract}
Disaster risks are very common occurrences within Kenyan secondary schools. Most disasters afflicting Nairobi City schools of the public category include fire outbreaks, student unrest, terror threats and strikes which have caused harm to humans and property in a number of incidences. Nevertheless, the concept of disaster risk management in secondary schools in Nairobi has so far not attracted much attention of researchers. The study objects were: to investigate school managers' training mode on DRM, how the training had assisted the school managers in DRM, and the influence of school managers' training on DRM. Emergent Norm theory and Risk Management theory were used to give guidance to the study. The study was a mixed methodology research employing concurrent triangulation design. The population comprised 282 individuals and sample size of 167 respondents determined according to Krejcie and Morgan sampling table. Data was collected through questionnaires and observation checklists for principals, HODs, BOM and interview guides for sub QASOs. Tools were pre-tested among $10 \%$ of the target sample, not part of part of the actual study. Instrument consistency was determined through Pearson product Moment correlation where a correlation coefficient of 0.75 was considered acceptable. Expert judgment by supervisors and peer reviewers was used to test the instruments for validity. Instrument dependability was established by employing overlapping procedures including telephone and face to face interviews during field work. Concurrent triangulation was employed for data credibility. Instrument reliability was calculated using Chronbach's Alpha. Quantitative statistics was descriptively evaluated and shown in figures and tables. Significance of confidence at 95\% level was tested using inferential statistics. Qualitative data was analysed thematically and results presented in tables. Conclusions are anticipated to benefit School managers, Teachers' Service commission, Parents, Principals, the Ministry of Education, Nairobi County. All ethical issues pertaining to research were observed. The study findings are that: School managers were not trained on management of disaster risks. The school managers were trained on school safety through: Red Cross, In-service and Work-shop programs. $71.3 \%$ of school managers said that DRM was negatively influenced by the training on disaster risk management. The researcher concludes as: School managers in public schools in Nairobi City are not trained on disaster risk management. $65 \%$ have been trained on school safety. School managers are not prepared to manage disaster risk because they lack appropriate training. The recommendations are that: The Government of Kenya should develop a policy for disaster risk management, a Curriculum on management of risks caused by disaster and train school managers, teachers, students and communities on management of disaster risk.
\end{abstract}

Keywords: influence, school managers' training, disaster risk management, modes of training, disaster risk

Cite This Article: Ignatius N. Munyiri, Ruth W. Thinguri, and Paul Edabu, "Influence of School Managers' Training on Disaster Risk Management in Public Secondary Schools within Nairobi City County Kenya." American Journal of Educational Research, vol. 7, no. 12 (2019): 948-956. doi: 10.12691/education-7-12-9.

\section{Introduction}

Training on management of disaster risk, forms a major component of programs intended for safety, prevention, mitigation and recovery from effects of disaster risk. The training on disaster risk management should aim to equip school managers with the requisite skills to be able to cushion the lives of students and all the staff including resources and general infrastcure within school premises.

\section{Background of the Study}

Disasters are catastrophes that cause significant physical damage and are not merely ornamental or interesting events that adorn our lives; they have 
undesirably continued to affect human beings since the dawn of our existence. They undermine hard work, development gains; destroy lives and livelihoods, trapping many people in poverty. In response, persons and communities as well, have made frantic efforts to reduce their exposure to the risks by developing measures to minimize their initial impacts including post cataclysm reaction. The disruption affects the ecosystem patterns, and normal life patterns requiring major emergency interpolations in order to rescue human lives including the environment. Disaster risk is brought about by a threat or mixture of threats, susceptibility and inadequate measures to decrease the plausible probabilities of its occurrence. Since catastrophes do not get expected, are sometimes unforeseen, yet they cause immense destruction to infrastructure and life, there is a great need for adequate training in preparation to identify their early warning signs, prevent them, mitigate and recover from their effect or halt them altogether.

Planning for training and preparedness on management of risks prompted by disasters comprises events, platforms and structures established preceding the onset of an adversity with the aim of supporting and enhancing extenuation responses, and rescue from sites of tragedy [1]. Such Planning includes the training, leadership, financial aid, readiness support and technical assistance to strengthen states, communities, professional emergency workers, local governments, and citizens in the preparation for identification of disaster signs, prevention, mitigation of results of disasters, response to needs of communities afterwards and introduction of operative rescue exertions [2]. Training on management of disaster seeks to decrease fatalities caused by perils, provide speedy and suitable help to the wounded and attain swift and tangible retrieval. According to Cavanagh [3], many children all over the world have died in the past, in preventable occurrences such as drug abuse and gun violence in the European and American schools, school fires and blasts in India and China, and school children massacre at Beslan in Russia due to lack of appropriate training on the part of institutional managers. After the disaster of 1993 when several school children were held captive by terrorists in Neuilly-sur-seine; a French commune just west of France, the police authorities have since undertaken to partner with school officials to coordinate security measures in schools. They convene every start of a new school session to map out the security plans.

Entrance to public learning institutions in the capital city of Paris are manned by police officers who are able to regulate the movement of people, check doubtful behavior, conduct search of all persons, luggage and vehicles, and provide security. In her endeavor to implement protection against fire on the basis of security program, Brazil could not find adequate specialists with the bias of protection and building resilience against catastrophe brought about by fire incidences who would provide assistance regarding the execution of fire safety measures [4]. According to the Red Cross Society of Kenya (2008), secondary schools are susceptible to disasters because they lack appropriate firefighting appliances, appropriate training like firefighting drills on the part of school managers and personnel, sufficient and suitable resources, including mitigation systems and instruments for response to disasters [5]. The state of fire disaster management and recovery is contributed by insufficient knowledge and awareness of the risk factors by school managers. In Kenya, violent incidences have been reported in schools leading to killings and destruction of properties [6]. A long such occurrences, School children become culpable to a wide range of behavior problems in the schools, oscillating between trivial punitive hitches and felonious persecution. Most developing countries including Kenya are vulnerable and very often suffer from various ordinary and technical (human-made) disaster invasion that cause appalling effects on the surrounding settings, economy and the entire human life mainly because of the unstable landforms and tropical climate combined with illiteracy, poverty, high population density, and lack of adequate infrastructure, [7].

\section{Statement of the Problem}

Schools around the globe have for a long time experienced various forms of disasters, including rape, fires, arson, road-accidents, terror-attacks, gang wars especially in Nigeria and USA and strikes across Kenya secondary schools [2,8]. In Kenya, management of public secondary schools has remained a challenge to most school managers for a long time especially with respect to disaster risks. For instance, a study by Ruto [9], disclosed that Kenyan institutions of learning had increasingly increased disrepute as boulevards of carnal mugging since the notorious assault on the girls of St. Kizito mixed secondary school by their male peers during a school strike. In the confusion, 70 girls were raped and 19 others were left dead.

These situations could however have been averted had the school managers been well trained and prepared to manage disaster risks. It is not clear whether an attempt has ever been made in assessing the effect of school managers' training on disaster risk management in Nairobi County community schools. Correspondingly, the presence of the Schools Safe Standards policy by the Government of Kenya notwithstanding, disasters have continued to ravage schools in Nairobi County; thus implying that a policy on training school managers on managing risks caused by disaster risk should be the panacea in realizing the Four Big Agenda, (sustaining the 100\% transition to secondary school) and effective realization of the nation's Millennium goals and the vision 2030.

\section{Purpose of the Study}

The research purposed to study how School Managers' Training influenced management of risks caused by disaster in Nairobi City public secondary schools.

\section{Research Objectives}

1. To examine modes used in training school managers in disaster risk managing in Nairobi institutions of learning in Kenya. 
2. To establish aspects of disaster risk managing that school managers were trained on in Nairobi City institutions of learning.

3. To survey the consequence of training institute managers on disaster risk management in Nairobi City public secondary schools.

\section{Research Questions}

1. What were the modes of training school managers on managing of disaster risk in public schools of Nairobi City Kenya?

2. Which Aspects of Disaster Risk Management were school managers trained on in institutions of learning in Nairobi?

3. How does the training of school managers influence management of disaster risk in institutions of learning in Nairobi?

\section{Rationale of the Study}

Nairobi is the capital city of Kenya, with a projected population of 4,390,158 by year 2018 according to a report by the National Census 2009, and so it portrays the face of the country. It is home to over 68 international organizations and many multinational institutions including all the Embassies and High Commissions representing various countries of the world in Kenya. Nairobi also houses the Head Quarters for UNISDRR Africa region together with many other UN institutions yet many schools within the city have continued to suffer from various forms of disaster risks. It also hosts over 91 public secondary schools with a student population of about 15,000 as at June 2016 [10]. It should therefore be expected that managers of schools in Nairobi are appropriately trained to management risks caused by disasters and that (DRM) best practices are practiced in schools within Nairobi City as the capital of Kenya and Headquarters for many UN organizations.

According to a 2016 report by the Nairobi County Director of education, schools in Nairobi have been facing numerous disasters including fire and arson, strikes and others and are under a threat of terrorist attacks. A dormitory burnt in Upper Hill secondary school, causing the death of a student, Jamhuri High School, Nairobi school, Moi Girls Nairobi, Dagoretti High and Lenana School, among others had all experienced incidences of unrest [10]. Generally, Schools in Nairobi had in several occasions been devastated by various forms of disaster which indicated that there was a need to survey the effect of school managers' training on managing catastrophic risk in Nairobi institutions of learning.

\section{Significance of the Study}

Products may offer insight for County Government of Nairobi, Government of Kenya policy makers, The Teachers Service Commission, and The Kenya Institute of Curriculum Development with regard to school managers training in preparedness for Disaster Risk Management.
Other stake holders including but not limited to:, The Education Science and Technology Ministry, School Managers, Parents, Donors, Suppliers, well-wishers and others may also find the results of this research useful because it may provide information regarding the mode of training the school managers have undergone, the aspects of Disaster Risk Management the school managers have been trained on in line with: identification of early warning signs for awareness, prevention, mitigation and recovery from disaster effects within schools in Nairobi and the influence of the preparation for management of disaster risk in secondary schools.

\section{Literature Review}

According to Hubbard [11], management of disaster risk involves the prioritization, assessment and identification of uncertainties before coordinating and applying economic resources to monitor control and minimize the possibility and/or effect of the ill-fated happenings. Disaster Risks in learning institutions can emanate from uncertainties such as accidents, fire, arson, diseases, terror attacks, theft, floods, windstorms, earthquake, insecurity, and pollution. Disaster Risk management can therefore be further defined as a process that identifies risk exposures, assess and prioritizes risk and applies appropriate techniques and resources to control and minimize the probability or effect of ill-fated occasions from happening. Managing peril is also important since it helps in maintaining and improving the employee performance both quantitatively and qualitatively, reduces employee absenteeism and turnover, minimizes institutional unrest and indiscipline, and improves employee morale and motivation [12].

Training on safety and health, forms a major component of programs intended for prevention of disaster risks. Information on potential hazards regarding the rules and how to avoid them is passed on through, training on Safety and general welfare [13]. Good health has several benefits including among others; minimization of jobrelated sicknesses and accidents, incidences of turnover, and absenteeism etc. Equally, the trickle down of benefits of good health can be traced in the improved teachers' morale, increased working period and better productivity and reduction of corruption on the part of employees.

According to Gichuru [14] most school stakeholders are trained on safety measures to ensure minimal occurrence of disaster risk. Nderitu [15] found out that, schools were greatly challenged by the lack of trained personnel for management of risk arising from disaster. Nakitto and Lett [16] and Armstrong [13], attest to the importance of training on fire safety plans in schools. Plans for safety from fire are central as they increase the level of management preparedness in the event of a fire onset. Accidents occurring due to unsafe acts can be attributed to absence of skills and know- how including wrong attitude of the workers [12].

Information on potential hazards regarding the rules and how to avoid them or mitigate their effects is passed on through, training on Safety [13]. Good health has several benefits including among others; minimization of job-related sicknesses and accidents, incidences of 
turnover, and absenteeism etc. Equally, the trickle down of benefits of good health can be traced in the improved teachers, other staff' and students' morale, reduction of dropout, increased working period, better productivity and reduction of corruption on the part of employees.

\subsection{Modes of School Managers' Training on Disaster Risk Management}

The mode of training for school managers on disaster risk management is very crucial in preparing them to deal with such events if and when they may occur. Every government should develop a curriculum for reduction of peril, promote the education on reduction of adversity on large scale and train educators widely [17]. As contained in that report, approaches to training of teachers should comprise: lectures delivered through face-to-face discussions and activities, pre-service training, i.e. providing regular training for teachers in the institutions, teaching academies as well as schools; and usually leads to the awarding of certificates. On-the-job training: the courses are taught over the week- ends or short time to practicing personnel, institutional based seminars or any other appropriate forums and process repeated for a period of time.

\subsection{How Disaster Management Training Assisted School Managers in managing disaster risk}

Training the populations on management of risks caused by disasters helps to reduce the proportional destruction and losses arising from calamities and even in a number of instances they may be stopped altogether. Professional Trainees should be imparted with adequate knowledge and requisite skills for reduction of risks brought about by disasters. Furthermore, there should be a campaign to educate all families, school children, school communities, teachers and school managers on the skills of management and recovery from disaster risk throughout the country [18].

Higher education programs for training of teachers and school managers should incorporate education for disaster resilience through durable and maintainable capacity-building in order to ensure that schools remain safe. The goals would best be achieved if there can be a move to Partner with all pedagogic institutions [19]. For the programs to remain relevant they should be continuously monitored and evaluated, reviewed and enhanced after implementation. School principals, who are responsible for ensuring effective operationalization and management of school curriculum, require appropriate training and preparation on leadership skills for the management and mitigation of impacts of risks prompted by disasters.

\subsection{Influence of School Managers' Training on Disaster Risk Management}

Higher education programs for training of teachers and school managers should incorporate education for disaster resilience through durable and maintainable capacity-building in order to ensure that schools remain safe. The goals would best be achieved if there can be a move to Partner with all pedagogic institutions [19]. For the programs to remain relevant they should be continuously monitored and evaluated, reviewed and enhanced after implementation. School principals, who are responsible for ensuring effective operationalization and management of school curriculum, require appropriate training and preparation on leadership skills for the management and mitigation of impacts of risks prompted by disasters.

Training the populations on management of risks caused by disasters helps to reduce the proportional destruction and losses arising from calamities and even in a number of instances may be stopped altogether. Professional Trainees should be imparted with adequate knowledge and requisite skills for reduction of risks brought about by disasters. Furthermore, there should be a campaign to educate all families, school children, school communities, teachers and school managers on the skills of management and recovery from disaster risk throughout the country [20].

A 2008 report by the UNISDR reveals that more than 100 post- secondary school programs for management of disaster risks are available on a researchable database developed and compiled by CADRRI in joint venture with the UNDP/BCPR and the UNOCHA that provides on-line courses, together with certificate courses for professional capacity building. A number of case studies have revealed that some programs for disaster risk reduction are available for local school administrators and QASO in such countries as: Madagascar, Maldives, Philippines; and the Lao PDR.

\section{Research Methodology}

The study was mixed methodology using Concurrent Triangulation Design. The process of gathering quantitative data was through questionnaires while qualitative data was collected through interviews. Concurrent triangulation research design was employed to establish the influence of school managers' training on disaster risk management in Nairobi public secondary schools. Emergent Norm theory and Risk Management theory were used to give guidance to the study. The study was a mixed methodology research employing concurrent triangulation design. The population comprised 282 individuals and sample size of 167 respondents determined according to Krejcie and Morgan sampling table. Data was collected through questionnaires and observation checklists for principals, HODs, BOM and interview guides for sub QASOs. Tools were pre-tested among $10 \%$ of the target sample, not part of part of the actual study. Instrument consistency was determined according to Pearson Moment Correlation and a correlation coefficient of 0.75 was considered acceptable. Expert judgment by supervisors and peer reviewers was used to test the instruments for validity. Instrument dependability was established by employing overlapping procedures including telephone and face to face interviews during field work. Concurrent triangulation was employed for data credibility. Instrument reliability was calculated using Chronbach's Alpha. Quantitative statistics was 
evaluated descriptively and results shown in figures and tables. Significance of confidence at 95\% level was tested using inferential statistics. Qualitative data was analysed thematically and results presented in tables. Conclusions are anticipated to benefit School managers, Teachers' Service commission, Parents, Principals, the Ministry of Education, Nairobi County. All ethical issues pertaining to research were observed. The study findings are that: School managers were not trained on management of disaster risks. The school managers were trained on school safety through: Red Cross, In-service and Work-shop programs. $71.3 \%$ of school managers said that DRM was negatively influenced by the training on managing risks caused by disaster. The conclusions of this study are: school managers of public secondary schools in Nairobi have not been trained on managing risks caused by disaster. $65 \%$ of them have trained on safety measures. Recommendation: The Government of Kenya should develop a policy on disaster risk management in schools. Develop a curriculum on management of disaster risk. Train school managers, teachers, students and communities on management of disaster risk.

\section{Research findings, results and interpretations}

\subsection{Modes of School Managers' Training on Disaster Risk Management}

Table 1. Modes of training on Disaster Risk management

\begin{tabular}{lcc}
\hline & Frequency & Percent \\
\hline Seminars, in-service and workshops & 46 & 28.8 \\
Formal training & 13 & 8.1 \\
Not trained & 56 & 35.0 \\
Red cross & 45 & 28.1 \\
Total & 160 & 100.0 \\
\hline
\end{tabular}

From the (65\%) school managers who had trained on school safety, (28.8\%) trained through seminars, in-service and workshops, (28.1\%) were trained by Kenya Red Cross while (8.1\%) attended a formal training. Some others (35\%) are not trained at all. These findings imply that school managers of public secondary schools in Nairobi are trained in different ways on safety management regarding DR while others are not. Further, the Government of Kenya does not emphasize on training school managers on management of disaster risks, yet national institutes are disposed to tragedies [10].

This leaves public secondary school managers with no option but to seek training on their own; hence dealing with emerging circumstances in an ad hock manner, a situation that exposes students, staff, school communities and the entire school facilities to high disaster risks. Similarly, Sallee [21], found that school head teachers were neither trained nor inducted on DRM and that there were no capacity building programs for them. They did not even possess basic First Aid skills.

Moreover, according to, UNICEF [16], the mode of training for school managers on disaster risk management is very crucial in preparing them to deal with such events if and when they may occur. Furthermore, the suggested approaches to training of teachers should comprise lectures delivered through face-to-face discussions and activities, pre-service training, such as providing regular training for teachers in the institutions, teaching academies as well as schools; usually leading to the awarding of certificates. Other methods include the on-the-job training where courses are taught over the week-ends or short time to practicing personnel, institutional based as well as seminars or any other appropriate forums and process repeated for a period of time.

\subsection{How the Training Assisted School Managers in Managing Disaster Risk}

With reverence to how the training received by school managers' had assisted in managing DRM findings are presented in Figure 1.

The findings in Figure 1 indicated that, $43.8 \%$ of school managers were able to administer First Aid during emergencies, $5.6 \%$ could prevent fire outbreaks, $6.2 \%$ could create awareness on the importance of DRM whereas the remaining 9.4\% could detect and respond to disaster as a result of the training they undertook. This means that the $65 \%$ of school managers that had been trained on one aspect or another of DRM were able to manage disaster risk in one way or another. This implies that there is no available organized curriculum for training school managers on management of risks prompted by disaster in Kenya. Further, even the training on school safety received by $65 \%$ of school managers was not compulsory. It's like the school managers attended the training at their own will and convenience. If there was a comprehensive Curriculum for training on management of disaster risks, there would not be these variations in training on aspects of school safety, given the importance of DRM in schools and the country at large.

Clearly, there is a lack of a training model for trainers on DRM, leaving school managers to train on what they feel is most comfortable for them, thus losing focus on very critical aspects such as identification of disaster early warning signs, preparation, prevention, mitigation and recovery. As Chien and Wen [22], aver, the education on prevention and reduction of disaster should be integrated into the regular school curriculum; Education for training of teachers on prevention of disasters on campus should be provided. Nakitto and Lett [15], also have contributed a voice in the importance of DRM training in schools by observing that training is important as it increases the level of management in case of a fire disaster.

\subsection{Influence of School Managers' Training on Disaster Risk Management}

Data was collected on the effect of training school managers' on DRM and findings presented in Figure 2.

Lastly, according to 75 (46.9\%), of the school managers, DRM was strongly negatively influenced by the managers training, 39 (24.4\%) mentioned that DRM was negatively influenced, $20(12.5 \%)$ said that it was greatly positively influenced, $10(6.2 \%)$ felt that it was positively influenced while $16(10 \%)$ said it was moderately but positively 
influenced. All respondents said that DRM was influenced by the school managers' training. The largest number 114 (71.3\%) said that the training influenced DRM negatively while only $46(28.7 \%)$ felt that it was positively influenced. This disparity is explained by the fact that some school managers had been trained on aspects of DRM in the school safety training, while others had not.

It implied that there was no organized DRM training for school managers in Nairobi County. As Ozmen [17], opines, education institutional managers are expected to oversee the curriculum instruction and managing the institutions under their care, and therefore, require appropriate training on reduction of risks caused by catastrophe to facilitate cases of mitigation of disaster risks and recovery. Every government should develop a curriculum for reduction of risks arising from disaster, train teachers as well as promote the teaching of reduction of risks prompted by disaster on large scale [16]. Furthermore, Turkmen et al. [23], observe that teacher training on DRM had been embraced at least at the pre-scale or experimental stage by various countries in the world including, Cost Arica, Cambodia, The Philippines, Japan, Lao, Armenia, and Fiji. The report further noted that the same form of DRM training had been practiced with fruitful results in countries like, Kazakhstan, Turkey, Indonesia and Madagascar.

\subsection{Inferential Statistics on Influence of School Managers' Training on Managing Disaster Risk}

Chi-square test was carried out to examine the association between the studied variables: influence of school managers' mode of training and disaster risk management. A comparison was carried out between the independent variables of school managers' mode of training and the dependent variable of disaster risk management. The test was conducted at 95\% confidence level.

Responses from the school managers concerning the two variables were captured using various questions including a five-point Likert scale which included: strongly disagree, disagree, neutral, strongly agree and agree. Data frequencies were keyed in into Chi-square on SPSS version 22.0 and the test results presented on Table 2.

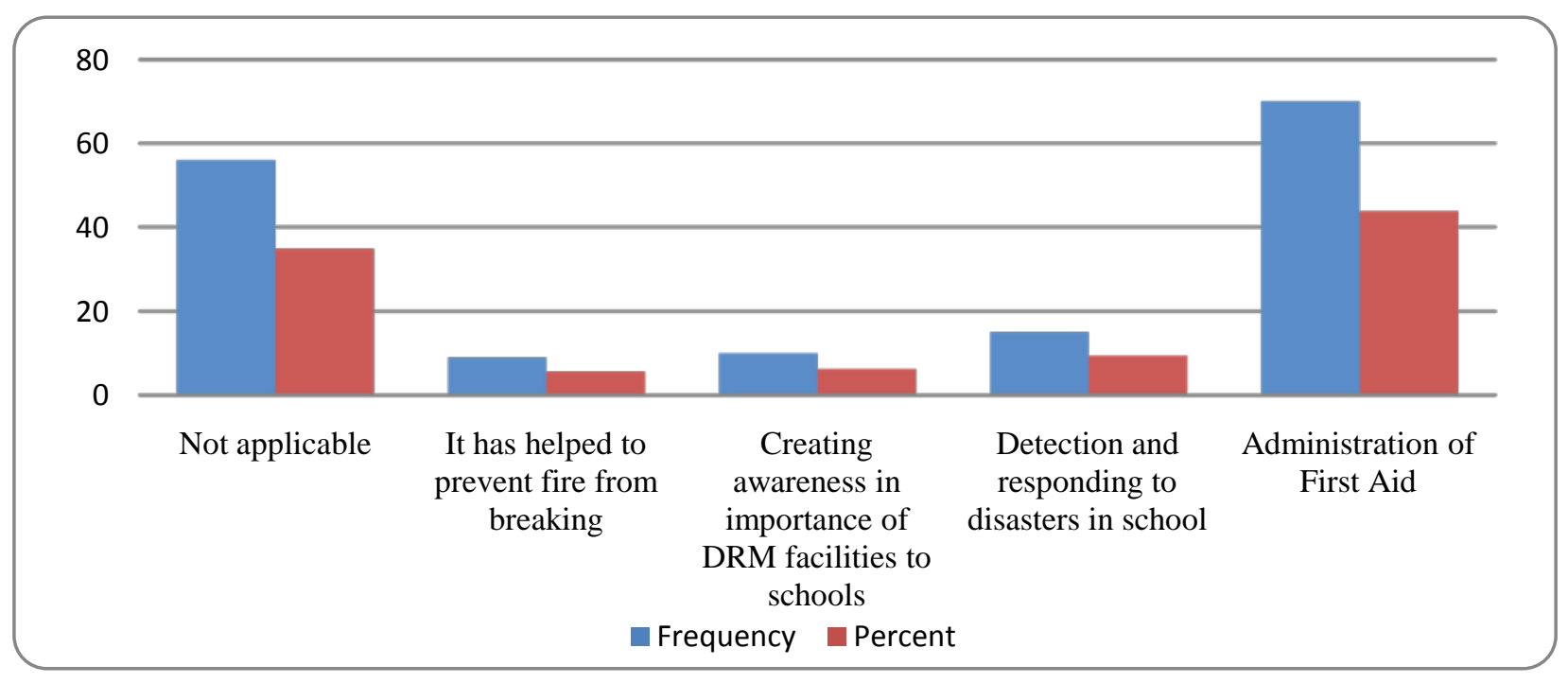

Figure 1. How Training has Assisted School Managers’ in Managing DRM

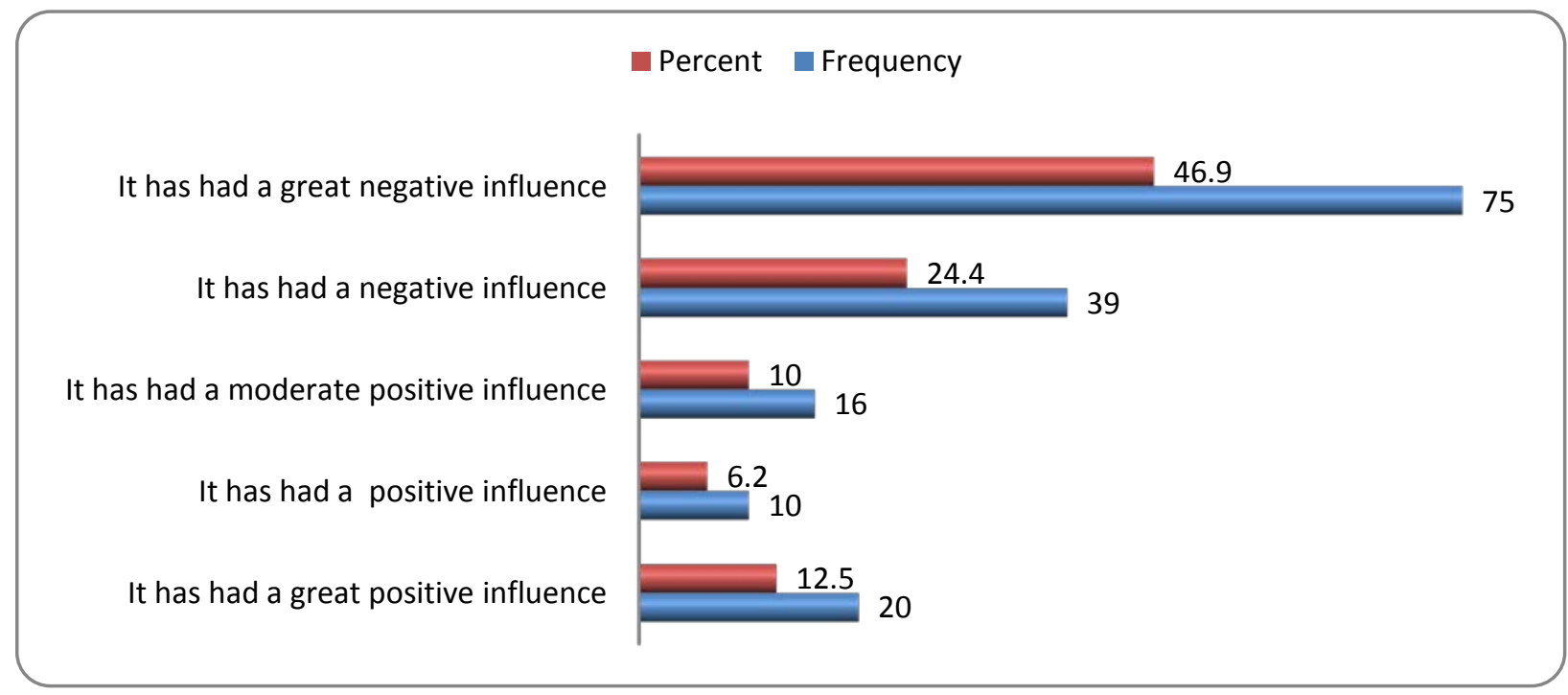

Figure 2. Influence of School Managers' Training on Disaster Risk Management 
Table 2. Chi-Square Test on School Managers' Training on school safety

\begin{tabular}{lccc}
\hline & Value & df & Asymp. Sig. (2-sided) \\
\hline Pearson Chi-Square & $2.331 \mathrm{E2}^{\mathrm{a}}$ & 12 & .000 \\
Likelihood Ratio & 261.093 & 12 & .000 \\
Linear-by-Linear Association & 123.371 & 1 & .000 \\
N of Valid Cases & 160 & & \\
\hline
\end{tabular}

The findings in the above Table indicate the relationship between school managers' training on disaster risk management and school management has statistical weight. At the level of confidence of $95 \%$, the calculated $\mathrm{p}$-value is $\mathrm{p}=0.000$ at the degree of freedom $\mathrm{df}=12$. With the $p=0.000$ being lower than $p=0.05$, the researcher accepts the existence of a statistically momentous affiliation amid school managers' training and management of disaster risk.

The strong correlation between the dependent and independent variables is however negative as indicated by the results. Therefore, in Nairobi County, school managers' training on DRM negatively influenced disaster risk management. This means since they have not undergone any training on DRM, then the training received by the school managers has had a negative influence on management of disaster risk. A Study by Turkmen, et al. [23], showed that the relationship between disaster risk management in schools and teachers training on management of risks arising from disaster was significant

The Chi-square test showed that there was a robust association involving the managers training and management of disaster risk. Results get supported by the National Disaster Management Authority of India which pioneered training to three hundred teachers from colleges linked to the university. The teachers were supposed to pass skills to the students of their colleges (The Times of India, 2009). This means there is great need to train the school managers, teachers, students and school communities on disaster risk management in Kenya as well.

\subsection{Thematic Analysis on Influence of School Managers' Mode of Training}

Sub-County QASOs were very clear about school managers' mode of training on management of disasters. Their interviews showed that the mode of training was wanting and needs to be improved.

"Public secondary school managers' have basic knowledge of DRM, even though, they are not well trained on the subject; an issue that compromises the ability to manage disasters" (Sub-County QASOs, 1, 2, 3 and 4)

The participants were also consistent in saying that the training received by school managers was very elementary. The training lasted for less than a week. This training according to them could not necessarily translate into better management of disasters in schools.

“Mainstream of public school administrators' in Nairobi County have had at least an hour's talk during the heads conference in 2016 on DRM" (Sub-County QASO 4)
"Most public secondary school managers' in this County have gotten at least some basic training in disaster risk management” (Sub-County QASO 2)

"In this County, most school managers' in public secondary schools have had a one-day workshop, meeting and seminar training on DRM" (Sub-County QASO 3)

There was a general feeling among the interviewees concerning the mode of training of school managers on DRM and management in schools. According to them, the mode of training received was found to influence DRM.

"The DRM training received by school managers has influenced DRM to some extent with respect to acquiring fire extinguishers and CCTV cameras" (Sub-County QASO1)

"The received training on DRM had no great influence since the training was a one day affair and did not equip the school managers well with the needed skills for managing disasters" (Sub-County QASO2)

"Most of the equipment for management of disaster risks is not available and buildings erected before 2008 are not risk compliant hence the training received by the school managers has not benefited them at all" (Sub-County QASO 3)

Interviewees noted that school managers training on DRM, influenced disaster risk management in schools. Installation of cameras and fire extinguishers were some aspects of DRM influenced by managers training.

"In most public secondary schools, the training has influenced availability of resources such as: CCTV cameras and fire extinguishers” (Sub-County QASO 1)

"School managers' training on DRM has greatly influenced fire management within community schools of Nairobi” (QASO 2)

"School managers' modes of training have greatly influenced disaster prevention and response within some community schools of Nairobi County” (QASO 3)

The outcomes showed that school managers were not adequately trained on disaster risk management. The training that was conducted for some school managers was so short that it could not impart the requisite information and abilities on prevention and management of disaster. The results from the interview also revealed that school managers' training, influenced management of disaster risks in Nairobi County.

The influence was however, negative in most instances as school managers had negligible levels of training on DRM. Therefore, school managers' mode of training was very low, leading to negative influence on the management of disaster risks. Turkmen, et al. [23], established the existence of a momentous association amid training of teachers on management of risks caused by catastrophe and management of disaster risks in schools in Turkey.

\subsection{Discussion of Research Findings}

The researcher summarized study findings based on the specific study objective on the influence of school managers' training on disaster risk management in Nairobi City County Kenya. 


\subsection{Influence of School Managers' Mode of Training on Disaster Risk Management}

Both the Emergent norm theory and Risk management theories which were cited to guide this study recognize that disaster risk management in any setting is influenced by a myriad of factors. The study revealed that $65 \%$ of public secondary school managers had received some form of training on school safety but none on disaster risk management. The said training was mainly through seminars, in-service and workshops while some others got trained through Kenya Red Cross; with a small group having attended formal DRM training but 35\% others had not been trained at all. Only $8.13 \%$ of the school managers' in Nairobi County public secondary schools had received a comprehensive training on school safety at college level. Those that were trained received training on aspects of: providing First Aid, learners' safety, basic disaster risk management such as type of resources needed in schools, and emergency response.

The training on school safety received by school managers enables them to administer First Aid during emergencies and prevention of fire outbreak. Generally, the mode of training greatly influenced disaster risk prevention, mitigation and recovery. Lastly, owing to lack of appropriate school managers' training, DRM in public secondary schools of Nairobi County is strongly negatively influenced.

Inferential statistics pointed to a statistically momentous correlation among school managers' training on DRM and management of risks caused by disaster in Nairobi City County Schools at 95\% confidence level. Campbell [24], observes that: "members of school community need to be educated on the plans for management of crisis in school. They are much more likely to accept the plan once they understand the rationale behind it. Furthermore, fear of a school crisis occurring is best managed by education". Campbell however did not specifically focus on school managers training on managing risks caused by disaster and its influence.

\subsection{Conclusions}

School managers have not been trained on DRM even though some $65 \%$ of them had received some form of training on school safety. 35\% others have not received any form of training. Furthermore, $29.42 \%$ of school managers received the training on safety through seminars, in-service and workshops, $27.78 \%$ were trained through Kenya Red Cross, 8.13\% through formal college training while $34.67 \%$ did not attend any training. The study findings also revealed that $65 \%$ of public secondary school managers in Nairobi County had trained on providing First Aid, general school safety and emergency response while $35 \%$ had not been trained to provide any form of safety in school. The School safety management training received by school managers has enabled them administer First Aid during emergencies and prevent fire outbreak. The results also established that most public secondary school managers' level of safety training greatly influenced disaster risk prevention, mitigation and recovery.
Lastly, management of disaster risks in $65 \%$ of Nairobi City schools is greatly positively influenced by the managers' training while in the rest (35\%), it has had negative influence. Inferential statistics further reveal existence of a statistically weighty association amid school managers' training and disaster risk management at 95\% confidence level. The researcher concludes that public Secondary school managers in Nairobi County are not trained on management of disaster risks in schools.

\section{Recommendations}

i. There is a need for public secondary school managers to improve their knowledge on disaster risk management through appropriate training. This is based on the fact that majority (65\%) of them have only received one day training on school safety during conferences but did not get trained on identification of disaster indicator signs, prevention, mitigation and recovery from disaster.

ii. The Government of Kenya should also provide a specific policy for training school managers, teachers, students and school communities on management of disaster risks; focusing on: identification of disaster warning signs, prevention, mitigation and recovery. This training would be best offered as a standalone item on the Curriculum owing to the magnitude of harm by disaster on human life. Disasters are everywhere in human life including the most familiar and comfortable surroundings. In fact, disaster and human beings are inseparable.

iii. The Government of Kenya should develop a course for managing risks caused by disaster in institutions of learning.

\section{Acknowledgements}

The researcher wishes to acknowledge the participants for their cooperation in providing data for this study.

\section{References}

[1] National Fire Protection Association, \& National Fire Protection Association. Technical Committee on Uniform Fire Code. (2006). NFPA 1 Uniform Fire Code. National Fire Protection Association.

[2] FEMA (2010). Bringing Youth Recovery Education to the Forefront: A literature Review and Recommendations. Issue6. [Online]: Retrieved from http://www.citizen/corps.gov.

[3] Cavanagh, T. (2004), October. Criminalising our schools: Effects on caring and nurturing teachers. Paper presented at the Invited Address (18 October 2004): School of Education, University of Waikato, Hamilton , New Zealand

[4] Tavares, R. M. (2009). Evacuation processes versus evacuation models: “Quo Vadimus”?. Fire Technology, 45(4), 419-430.

[5] MOEST. (2001). Report of the Task Force on Student Discipline and Unrest in Secondary Schools. Nairobi: Jomo Kenyattta Foundation.

[6] NACADA (2002). Drug and Substance Abuse: The Kenyan Context. Nairobi: NACADA News.

[7] Alexander, D. (2002). Principles of Emergency Planning and Management. Harp ended: Terra, Publishers. 
[8] Savula A., \& Atsiaya P (2004). Grilles order to school heads. The Standard p.4. Nairobi: Standard Group

[9] Ruto, J .S (2009). Sexual Abuse of School Age Children. CICE Hiroshima University, Journal of International Cooperation in Education, Vol.12 No.1 (2009) Pp 177-192.

[10] Hubbard, D. (2009). The failure of risk management: Why it's broken and how to fix it. Hoboken, N.J: Wiley.

[11] Nairobi County Director of Education, (2016).

[12] Khanka, S. (2011). Human Resource Management. Published by S. Chad \&\ company Ltd, New Delphi, India.

[13] Armstrong, M. (2009). Armstrong's handbook of human resource management practices (11th Ed.). London: Kogan page.

[14] Gichuru, J. (2013). Fire disaster recovery strategies in secondary schools In Nyeri Central District, Kenya. Unpublished M.ED. Project.

[15] Nderitu, C. (2009). Implementation of safety standards guidelines in secondary schools in Githunguri Division, Kiambu District. Unpublished MEd project, Kenyatta University.

[16] Nakitto, M. \& Lett, R. (2012). The recovery of Ugandan schools for fire. Makerere Medical School.

[17] UNICEF (2009). Concept Note. Disaster Risk Reduction in UNICEF. Towards safer and resilient communities for children. National Progress Report on the Implementation of the Hyogo Framework of Action 2009-2011.
[18] Ozmen F. (2006). The level of recovery of the schools for disasters from the aspect of the school principals. Disaster Prevention and Management Vol. 15 No. 3, 2006 pp. 383-395.

[19] UNISDR, (2008). Disaster Prevention for Schools: Guidance for Education Sector Decision-Makers. Consultation Version, November 2008. Geneva: International Strategy for Disaster Reduction Thematic Platform for Knowledge and Education.

[20] Orodho, A. (2012). Elements of Educational and Social science Research Methods: $2^{\text {nd }}$ edition Kenezja Publisher, Maseno, Kenya.

[21] Sallee, R. E. (2011). Closing the Teaching Gap: Professional Development Programs that Work. ProQuest LLC. 789 East Eisenhower Parkway, PO Box 1346, Ann Arbor, MI 48106.

[22] Chien, Y. \& Wen, C. (2012). "Damages to school infrastructure and development to disaster prevention education strategy after Typhoon Morakot in Taiwan", Disaster Prevention and Management: An International Journal, Vol. 21 Issue: 5, pp.541-555.

[23] Turkmen, Z. \& Tüzün, C. (2010). The Issue of Disasters and Emergencies Training in Turkish Ministry of Education National Primary School Curricula. Istanbul: unpublished but submitted to the Ministry of National Education, September. http://ztscompany.com/EN/articles.html

[24] Campbell, J. P., DeBlois, P. B., \& Oblinger, D. G. (2007). Academic analytics: A new tool for a new era. EDUCAUSE review, 42(4), 40. 